were in the most confidential communication relative to our various works on the Crinoids, especially the one now in progress. We always interchanged advance sheets of our publications, and sometimes sent each other manuscript for examination and criticism. Carpenter was always the soul of honour in regard to information derived from these private communications, and was generous to the last degree in giving information from his great store of learning, whose value none could estimate higher than we. I should be very glad to know of any publications in England in recognition of his merits.

Hoping this will find you very well, believe me always, very sincerely yours,

Las Vegas, New Mexico, November 15th, 1891.

Frank Springer.

"ANNALS OF BRITISH GEOLOGY" FOR 1890.

SiR,-It is not my intention to make any comments on the criticisms which the compiler of the volume bearing the above title has thought fit to introduce into the notices of my papers, as those who have even the most superficial acquaintance with the subject therein treated will be able to appreciate the value of such criticisms. When, however, I am deliberately charged with making a blunder, which exists only in the mind of the compiler, it is time to say something. In noticing the fourth part of my "Catalogue of Fossil Reptilia and Amphibia," the compiler of the work in question goes out of his way to state that I have changed the names Orthocorta to Orthopleurosaurus without giving any reason for so doing. Now (withont commenting on the circumstance that he had the reason for this change staring him in the face), if the compiler had taken the trouble to look at the notes at the bottom of the page, he would have seen after the reference to the name Orthocorta, the word "Hybrid."

R. LYDEKKER.

\title{
UNCONFORMITIES BENEATH THE CAMBRIAN QUARTZITES IN
} SHROPSHIRE.

Sir,-In the Geological Magazine (1891), p. 485, is a paper by the Rev. J. F. Blake, in which he challenges some of my criticisms on his work in Shropshire. His chief assertions are the following :

(1). That at Pontsford Hill the Longmynd Rocks in contact with the Rhyolite are altered.

(2). That at Narnell's Rock there is an unconformity separating Cambrian from "Monian" rocks.

(3). 'That at Charlton Hill the conglomerates and grits are superficial, and are not a part of the Uriconian series.

Paper-contests in geology are rather unsatisfactory work, and I therefore propose to attempt a settlement of these disputed points, and any others that may be agreed upon, in the following manner. A competent geologist, to be selected by Mr. Blake and myself, to visit the ground in our company, and to publish his conclusions. The disputant who is convinced of his error to publish bis recantation. The disputant against whom the referee decides in the 
majority of cases to pay the travelling expenses of the referee. I am aware that disputes cannot always be settled in this way; but the three sections I have named are so clear and simple, that a third party can hardly fail to come to an immediate decision, and we should select a person whose award would carry weight. If $\mathrm{Mr}$. Blake refuses this challenge, I will offer to take any competent geologist to the sections, and to forfeit five gunieas to a hospital if I fail to convince him.

November 20th, 1891.

Ch. Callaway.

\section{" CONCRETIONS" IN MAGNESIAN LIMESTONES.}

SIR,-There is another possible method, besides those suggested by Messrs. Garwood and Jukes-Browne, by which the globular and pseudo-coralline and other forms so remarkable in the Magnesian Limestone of Durham may have originated-the mechanical; and this is slightly alluded to by Professor Sedgwick (page 92).

Many years ago a friend presented me with a considerable series of specimens obtained from the neighbourhood of Sunderland; their examination seemed to indicate that their forms were due to mechanical action, but it was difficult to imagine how the principle on which a school-boy's marbles, "alleys, tors and commoners," are formed from cubical fragments of stone, could have been applied by natural means; nor did a visit to the extensive quarries at Fulwell, north of Sunderland, assist in solving the problem. The promontory on which Tynemouth Castle stands may possibly help to afford a solution. The strata forming the base of the cliff consist of Coalmeasure Sandstone, on wbich rests a bed composed of angular fragments derived from the same, and over this the Permian Limestone has been deposited. This Limestone is full of cavities resembling in appearance some examples of vesicular trap.

I would suggest that during the formation of the limestone, and whilst it was still in a more or less plastic state, gases evolved from the decomposition of vegetable matter forming beds of Coal made their way through the basement beds of limestone. Such vesicles as occur at 'Tynemouth might be expected to have been formed under these conditions, and it is quite possible that the globular forms of the so-called "concretions," which occur near Sunderland, may have originated from a similar cause, though under somewhat different circumstances, such as the amount of gas evolved; the amount to which the lately deposited limestone had consolidated, etc. Whatever was the cause of the fashioning of the globular masses, the same must have been the instrument by which the coral-like forms were shaped.

I much regret being so circumstanced that I could not conveniently carry out a series of experiments to determine the possibility of the globular forms being due to the cause suggested. The only rough attempt made was so far satisfactory that the passage of carbonic acid, generated beneath clay in a plastic state, resulted in the production of many small rounded forms.

BIrkenhzad, November, 1891.

Charles Ricketts. 